\title{
日常物体の視覚探索における探索非対称性と色の影響
}

\author{
永井 淳一 \\ （聖心女子大学 文学部）
}

key words : 視覚探索, 探索非対称性, 視覚的注意, 色の影響

妨害刺激の中から標的刺激を探し出す視覚探索の実験では, 標的刺激と妨害刺激を入れ替えることで，探索効率が著しく 変化する場合がある。この現象は「探索非対称性」と呼ばれ， 一般的に, 親近性の高い項目の中から親近性の低い項目を探 索する場合の方が，その逆よりも探索が効率的になる傾向が 知られている。たとえば，刺激に動物のシルエット画像を使 用した Wolfe (2001) の実験では, 倒立のゾウの中から正立の ゾウを探す場合に比べて, 正立のゾウの中から倒立のゾウを 探す場合の方が容易であるとの結果が得られている。

本研究では, 日常物体 (果物・野菜) の写真を用いて Wolfe (2001) の追試を行うとともに，写真をカラー・グレースケー ル・不適切色で呈示した場合を比較し，探索非対称性への色 の影響を検討することを目的とする。Nicholson \& Humphrey (2001) は，色の手がかりによって回転した物体の認知が容易 になると報告している。適切な色の手がかりによって物体の 親近性が高くなるならば，カラー写真の場合には正立・倒立 の刺激間で探索非対称性が消失することが予想される。

\section{方 法}

実験参加者 正常な色覚・視力をもつ聖心女子大学の女子 学生 24 名が個別に参加した。

刺激 色との繋がりの強い 4 種類の物体(リンゴ,バナナ, ナス, ピーマン) の正立像と倒立像を使用し, カラー・グレー スケール・不適切色（色相反転）の 3 通り（ブロック化）で 呈示した。目標刺激と妨害刺激は常に同じ物体とし, 前者が 正立ならば後者は倒立, 前者が倒立ならば後者は正立で呈示 した。これらは半径約 $11^{\circ}$ の仮想円上に等間隔で配置した。

実験計画 各ブロックともに, 目標刺激の呈示方向 (正立・ 倒立), 目標刺激の有無, セットサイズ $(4,6,12)$ の 3 要因 の参加者内計画 $(2 \times 2 \times 3)$ であった。

手続き・課題 3 通りのブロックの実施順序は参加者間で カウンターバランスした。1 回の試行では, 注視点 $(500 \mathrm{~ms})$
の後に探索画面が反応まで呈示された。実験参加者の課題は 探索画面の中に 1 個だけ呈示方向の異なる目標刺激が含まれ ているか否かの判断であった。

\section{結果・考察}

結果を Figure 1 に示した。カラー写真の条件（A）では, 刺激の呈示方向によって探索効率に殆ど差が見られず，3要 因分散分析では目標刺激の有無とセットサイズの両主効果, 両要因の交互作用のみが有意 $(p \mathrm{~s}<.01)$ であった。これに対 して, グレースケールの条件（B）では, 目標刺激が正立の 場合に探索関数の傾きが急になる傾向が見られ，3 要因分散 分析では, 目標刺激の有無・セットサイズの両主効果と両要 因の交互作用に加え, 刺激の呈示方向とセットサイズの交互 作用も有意 $(p \mathrm{~s}<.01)$ であった。なお, 不適切色の条件 $(\mathrm{C})$ では, 目標刺激の有無・セットサイズの両主効果と両要因の 交互作用 $(p s<.01)$ の他, 呈示方向の主効果と 3 要因の交互 作用が有意 $(p \mathrm{~s}<.05)$ であった。

グレースケール条件における呈示方向とセットサイズの交 互作用は探索非対称性の生起を示し, Wolfe (2001) を追認す る結果である。一方, カラー写真の条件ではこの交互作用が 有意ではなかったことから, 予測のとおり, 探索非対称性の 消失が示されたといえる。不適切色条件に関しては 3 要因の 交互作用が有意であり，慎重な解釈を要すると思われる。

\section{引用文献}

Nicholson, K. G., \& Humphrey, G. K. (2001). Surface cues reduce the latency to name rotated images of objects. Perception, 30, 1057-1081.

Wolfe, J. M. (2001). Asymmetries in visual search: An introduction. Perception \& Psychophysics, 63, 381-389.

\footnotetext{
†本研究は, 著者の指導により桑田有未さんの卒業研究 (2006
} 年度・聖心女子大学文学部教育学科) として行われた。

(NAGAI Jun-ichi)
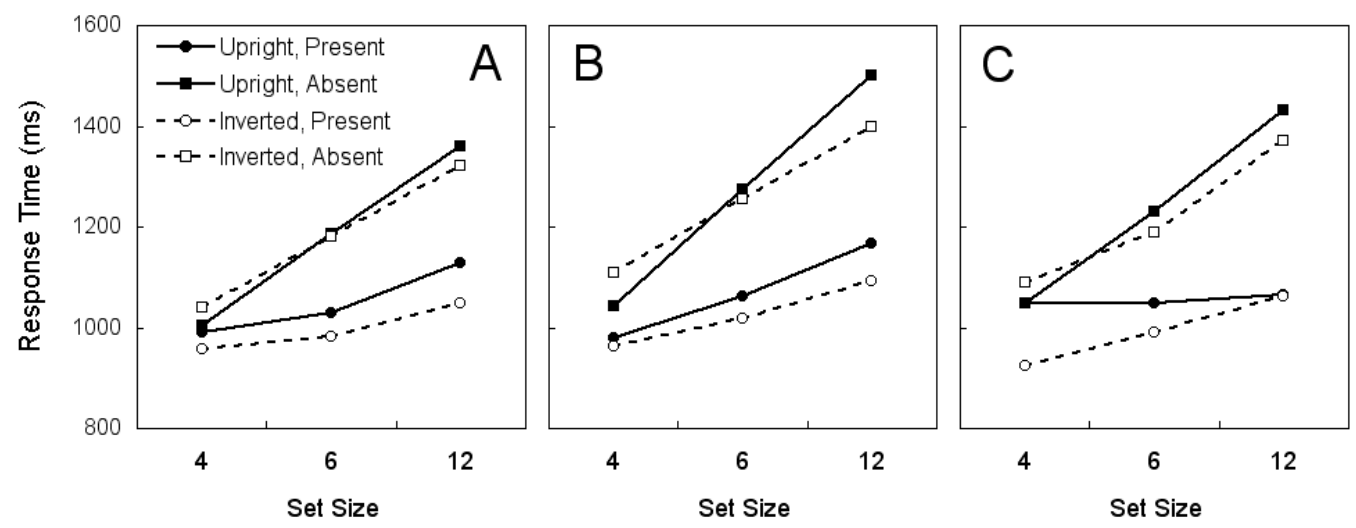

Figure 1. Mean median response times as a function of target orientation, target presence, and set size in each condition of object color (A: normal color, B: grayscale, C: abnormal color). 